\title{
Role of Community in Mitigating Dehumanizing Effects of Racism in Toni Morrison's Works
}

\author{
Dr Shikha Goyal \\ Principal \\ Mukhtiar Singh Memorial Degree College \\ Behbalpur, Fatehabad, Haryana, India \\ drshikhajcd@gmail.com
}

\begin{abstract}
Discrimination is the prejudicial treatment of an individual or a group based on their actual or perceived membership in a certain group or category in the society. It can be either direct or indirect and may be in various forms and patterns depending upon the cultural background and milieu of a particular country or region. Discrimination has multiple ramifications related to exclusion from economic entitlements, basic services and opportunities on one hand and humiliation, subordination, exploitation and denial of citizenship rights on the other. During colonization, the indigenous cultures of those countries were often sidelined, suppressed and openly denigrated in favour of elevating the social and cultural preferences and conventions of the colonizers. Toni Morrison tries to explore various cultural aspects, processes of marginalization as well as decolonization and asserts that the richness and validity of indigenous cultures in an effort to restore pride in practices and traditions that were systematically degraded under colonialism. The present paper aims to explore various approaches adopted by the characters in her fiction to cope up with the discrimination inflicted upon them particularly the positive role of community.
\end{abstract}

Keywords: Discrimination, Prejudice, Subordination, Indigenous, Colonialism, Mitigation 
The history of blacks in America has invariably been one of victimization and oppression and the interracial violence manifested in whipping, lynching, branding and various other tortures, race riots, and the brutality of white police. Blacks were uprooted from their native land Africa and robbed of their culture under the system of slavery.

Nothing has been more common in human history than discrimination against different groups, whether different by race, religion, caste or in innumerable other ways. Moreover, this discrimination has itself been unequal- more fierce against some groups than others and more pervasive at some periods of history than in others. (Sowell 8)

Morrison in her fictional works presents the blacks' unbearable traumatic experiences of colonialism and how the dominant robbed them of their ancestral roots, family and the sense of self-worth. The Africans, transported from their native country, uprooted from its rich traditions and culture, were replanted in a strange and hostile soil. Margaret Atwood in "Haunted by Their Nightmares" points out disoriented black family, "The slaves are motherless, fatherless, deprived of their mates, their children, their kin. It is a world in which people suddenly vanish and are never seen again not through accident or covert operation or terrorism, but as a matter of everyday legal policy" (7).

In all of Morrison's novels, the black community is, from one perspective, largely defined by the dominant white society and its standards. All the characters in Morrison's novels exist in communities that are defined by the racial barrier formed by the surrounding white society. The experiences of displacement resulted in identity problems among the colonized which Morrison presents in Beloved. As a slave, Baby Suggs is constantly forbidden to retain (intimate) relationships with her family and friends. Being a slave, she finds each familial identity conflicts with her slave identity and it has taken away her name and she is known by the name on her bill-of-sale Jenny Whitlow. Therefore, she notices she 
has no self: "the sadness was at her centre, the desolated centre where the self that was no self made its home" (Morrison, Beloved 165). She tries to imagine what she would be like if slavery had not denied her from forming relationships with her family and friends, "Was she a good friend? Could she have been a loving mother? A faithful wife? Have I [Baby Suggs] got a sister and does she favor me? If my mother knew me would she like me"? (165)

Stamp Paid in Beloved too is a victim of emotional emasculation that slavery executed on slaves. Stamp Paid was forced to give up his wife to the vicious lust of his white master's son. The experience of Stamp was far worse and he believes, " anybody white could take your whole self for anything that came to mind. Not just work, kill or maim you, but dirty you. Dirty you so bad you couldn't like yourself anymore. Dirty you so bad you forget who you were and couldn't think it up" (251).

Tar Baby clearly indicates the double consciousness related to the identity of black in the racialized society. The confusion of Jadine regarding her belongingness is in tune with Beaulieu comment about the predicament of characters of Morrison, "in order to survive, Morrison's characters need to choose whether to exist in the shadows, submerging their identities, or to fight back, proving that they have a self worth respecting" (170). It is believed by Morrison that the self appraisal, the self-esteem also plays a role in negating the hazardous effects of racism. It seems a regular feature in Toni Morrison's fiction that the black characters long for and strive hard for a positive self image connected to a community. The belongingness and craving for family relations and community is dominated by a sense of survival and to subdue the pangs of racial and other forms of oppression.

A close study of her novels reveals that Morrison wants to establish through her novels that people can subdue the pain of racial discrimination, pangs of hunger and poverty by establishing a bond of love, care and worth among the family members. The positive role of ancestral roots and community are presented in her works as powerful means to cope up 
with the dehumanizing effects of racial discrimination and to regain one's sense of worth and self. In Beloved the character of Stamp Paid shows how personal aggression is contained, controlled and re-channelized for the welfare of others as a strategy of enlightened adjustment. Unlike others his awareness of oppression is not personal. The red ribbon is a reminder of the mass racial hostility. Though like Baby Suggs, he too feels worn out, yet "in spite of his exhausted marrow, he kept on" (Morrison, Beloved 222).

The MacTeer family in The Bluest Eye believes that racial hegemony is something that is internalized through childhood exposure to it. It is being taught through day to day practices and experiences because it is not naturally acquired. But the supporting family culture provides a sufficient immune system and moderation to balance the contradiction. As a result unlike Pecola, Claudia and her sister Frieda are happy with their difference, their blackness, "Guileless and without vanity, we were still in love with ourselves then. We felt comfortable in our skins, enjoyed the news that our senses released to us, admired our dirt, cultivated our scars, and could not comprehend this unworthiness" (Morrison, The Bluest Eye 57).

Claudia in The Bluest Eye is a strong character like Sethe and Sixo and she is not the victim of the adoration of white beauty as a child. On the contrary she has a feeling of hatred and repulsion for it. She does not enjoy the girls' talk about Shirley Temple. Claudia's consciousness can also be read as a stage of decolonization of mind. Grewal asserts, “Individuals collude in their own oppression by internalizing [the] dominant culture's values in the face of great material contradictions" (21). Moreover, she doesn't like the Christmas gift of the big, blue eyed baby doll. She is not fascinated by the beauty of the white girl. She wants to know the reason why these are termed as beautiful, why everyone aspires for it, why she is looked down upon by others and what is the reason behind this discrimination. Finally, she comes to the conclusion: 
And fantasy it was, for we were not strong, only aggressive; we were not free, merely licensed; we were not compassionate, we were polite; not good but well behaved. We courted death in order to call ourselves brave, and hid like thieves from life. We substituted good grammar for intellect; we switched habits to simulate maturity; we rearranged lies and called it truth, seeing in the new pattern of an old idea the revelation and the word. (Morrison, The Bluest Eye 163)

Morrison underlines the importance of black history and culture in Tar Baby also. White standards and white beauty have become less important than in her earlier novels. It seems that Morrison is trying to say that even if blacks have a choice, or more choices than they did in the past, they should never give up their black roots in exchange for whiteness. This statement is reinforced by one of the last pages of the novel, where Thérèse tells Son to forget about Jadine, "She has forgotten her ancient properties" (Morrison, Tar Baby 308). Through Son Greene, who is defined by his black cultural heritage, Morrison suggests that cure for modern spiritual bankruptcy faced by the black youths lies in their renewed attempts to establish kinship with their past history, culture and community. Rigney aptly remarks "In Morrison's fiction, identity is always provisional; there can be no isolated ego striving to define itself as separate from community" (55).

In Home Frank in his way to rescue his sister also rescues himself and re-emerges out of his horrible past to reclaim and assert his self amid the forces of antagonism to give a new meaning to his life. He stands against the social, economic and psychological pressures he encounters in white America through hard-work, strong and stable family ties and by defining himself according to his own cultural values instead of the values of the dominant culture. He gains his true self and achieves an authentic existence by connecting himself to his African heritage, culture and community values. Finally the burial of the dead man who was forced to 
fight like a dog with his own son brings Frank back to his own self and sense of worth as a human being. He paints on the wooden marker, "Here Stands A Man" (Morrison, Home 145) and by doing this he reclaims the native cultures by challenging the colonial misrepresentations. Frantz Fanon aptly states, "Black men want to prove to white men at all costs, the richness of their thought, the equal value of their intellect" (Black Skin, White Masks 10). The impact of oppressive practices of the dominant can be mitigated by considering one's inherent strength and by being comfortable in one's skin. It takes a lot of courage to see that and accept it, but it's true as in Home, Morrison writes:

I can be miserable if I want to. You don't need to try and make it go away. It shouldn't go away. It's just as sad as it ought to be and I'm not going to hide from what's true just because it hurts. Cee wasn't sobbing any more, but the tears were still running down her cheeks. (131)

Thus, Morrison has presented various approaches adopted by the characters in their fiction to cope up with the discrimination inflicted upon them. Pecola, Geraldine and Pauline in The Bluest Eye accept themselves as inferior and try to mould themselves through de-culturation and assimilation to the dominant culture. Jadine in Tar Baby assimilates in the white culture, but throughout the novel she suffers from the double consciousness and remains in dilemma about her cultural values and ancestral roots. Cholly in The Bluest Eye and Frank in Home internalize the violence imposed on them by the dominant group. It is strong characters like Sixo in Beloved, Claudia in The Bluest Eye, Miss Ether in Home, and Son in Tar Baby who celebrate their cultural roots and are comfortable in their own skin. Baby Suggs accepts her inferiority but not to imitate dominant cultures values and after her emancipation she develops her individual self. She re-establishes the cultural values of love, care, and belongingness to her community. 
Finally, it can be concluded that according to Morrison white cultural supremacy and racial discrimination in American society have resulted in the disintegration of the blacks and fragmentation of their families and as such it has caused the separation of the blacks from the white mainstream. Therefore the blacks, who are victims of American racist society, must struggle hard to reclaim their lost identity in Afro-American context, if they have to exist and have their culture preserved at all. Otherwise the whole group of blacks will be denied the right to create a recognizable identity as individual or as community. In this way she in her works tries to make invisible and disenfranchised communities discernible and vocal. 


\section{Works Cited}

Atwood, Margaret. "Haunted by Their Nightmares." Viva Modern Critical Interpretations: Toni Morrison’s Beloved. Ed. Harold Bloom. New Delhi: Viva, 2007.5-9.Print.

Beaulieu, Elizabeth Ann, ed. The Toni Morrison Encyclopedia. London: Greenwood, 2003. 150-75.Print.

Fanon, Frantz. Black Skin, White Masks. Trans. Charles Lam Markmann. NY: Grove, 1967.Print.

Grewal, Gurleen. Circles of Sorrow, Lines of Struggle: The Novels of Toni Morrison. Baton Rouge: Louisiana State UP, 1998. Print.

Morrison, Toni. Beloved. NY: Alfred Knopf, 1987. Print.

Rigney, Barbara. "Hagar's Mirror: Self and Identity in Morrison's Fiction.” Peach, Linden. Toni Morrison. London: MacMillan,1998.52-69.Print.

--- . Tar Baby. NY: Alfred Knopf, 1981.Print.

---. Home. London: Vintage, 2013. Print.

---. The Bluest Eye. NY: Holt Henry, 1970. Print.

Sowell, Thomas. "Race, Culture, and Equality.” Hoover Essays. Stanford: Hoover Institution Press, 1998. 1-15. Print. 